Fatih Perçin

Ege University, fatihpercin@gmail.com, İzmir-Turkey

\begin{tabular}{l|l}
\hline DOI & http://dx.doi.org/10.12739/NWSA.2018.13.4.E0038
\end{tabular}

ORCID ID $0000-0002-5118-8061$

CORRESPONDING AUTHOR Fatih Perçin

\title{
JOB SAFETY AND ACCIDENTS IN MARINE FISH FARMS (SEA BREAM/SEA BASS) IN IZMIR/TURKEY
}

\section{ABSTRACT}

Occupational health and safety, and accidents are one of the main problems in Turkey. Many workers, engineers, supporters and employers are affect from them. Especially, fisheries and aquaculture area have a black hole. Because, registration or information of safety or accidents knowledge could not enough record. Marine fish farms, hatcheries, nursery fields, and cage systems or grow-out phases are dangerous areas of workplace and need prevention. İmir is an important area for marine fish farms, hatcheries and sea cage structures in the Aegean Sea, western part of Turkey. Many employees are affect form duty work conditions, night shifts, and accidents etc. In the research, three marine fish farm which cultured sea bass/sea bream, was examined in northern and western side-Çandarlı and Çeşme area - of İmir province, Aegean sea. Face to face survey conducted with workers and descriptive tests SPSS was using with data. According to results, many employees are effect form work stress such as; fish tanks or ponds and narrow areas (85\%), working at height areas (78\%), wet slippery floor (75\%), electrical currencies (72\%), chemicals and disinfectants (70\%), heavy working conditions (70\%), physical conditions - hot, cold, humidity (65\%), biological risk factors such as infections (65\%), psychosocial risks and shift works (60\%) for hatchery phases. Also, heavy duty conditions, pressure for underwater divers, biological risk factors, infections, and psychosocial risks are other risky areas for grow-out cage workers and nursery phase workers. On the other hand, main health problems and factors are grouped such as; musculo skeletal problems and accidents, fractures, dislocations, and poundings (90\%), skin problems or allergy (86\%), eye and ear problems (85\%), respiratory problems mainly caused by physical risk factors (82\%), gastrointestinal disorders which is related with irregular nutrition (78\%), psychosocial problems mainly heavy duty terms and shift works. Also, low incomes are affecting to workers' health.

Keywords: Occupational Risks, Safety, Accidents, Aquaculture, Marine Fish Farm

\section{INTRODUCTION}

Occupational health and safety legislation and rules are very important in this decade. Especially in Turkey, many of disease and accidents are related with education, careless, lack of awareness and ignorance and heavy duty work conditions [1, 2, 3, and 4]. One of the significant and threatened areas of occupational workplace is fisheries and aquaculture sector. Many of labors and support employers are serious risk factors such as fatal accidents, acute or chronic disease impacts on the sea or coastal zones [5 and 6]. Thus, it can be

How to Cite:

Perçin, F., (2018). Job Safety And Accidents In Marine Fish Farms (Sea Bream/Sea Bass) In İzmir/Turkey, Qualitative Studies (NWSAQS), 13(4):30-32,

DOI: $10.12739 /$ NWSA.2018.13.4.E0038. 
very concluded that fractures, dislocations, bruising, swelling, even it organ ruptures are effect to the fisheries and aquaculture workers.

In Turkey, aquaculture and fisheries area have contain various different working structures. The former, aquaculture, has comprise animal farming, plant farming, project systems, economy and business, and fish diseases. The latter is involve large scale fisheries, small scale fisheries, industrial fisheries, recreational fisheries, harbor systems, seafood markets and fisheries management [6, 7, and 8]. One the other hand, some working areas in both basic trunk are transitive for instance; between animal farming and seafood market or small scale fisheries, also economy, business and management. Thus, working places of these area is need to intensive work zones. Hence, new problems, laws, rules, legislations arise daily. One of the profitable aquaculture region is sea bream and sea bass farms. Those farms are manly settle off to the coastal zone and they have contains many parts such as hatchery places, cages systems and constructions, feeding systems and logistic areas near the sea and central management area $[6,7$, and 8]. Thus, the places have includes risky conditions and terms and severe requirements. Job security and health preventions are important for the places which keep employee and job provider.

\section{RESEARCH SIGNIFICANCE}

Many of the aquaculture workers have to encounter accidents or diseases factors or heavy working conditions. Trends in marine aquaculture is increase and great companies are founded in İmir region. The aim of the research is to describe threatened factors which leads to accidents and diseases in fragile workplaces, sea bream and sea bass farms in İzmir province.

\section{EXPERIMENTHAL METHOD-PROCESS}

The researchers are worked in three sea bass and sea bream farms in İmir. Two of them is settled in north of the city, Çandarlı, one of them is near the Çeşme, west part of İmir, Aegean Sea. In the workplace, sea cage and hatchery areas, it can be interviewed with 32 employee to state threatened factors in the farm places or enterprises such as dangerous area, critical decisions or risky behaviors. In addition, face to face survey conducted with workers and descriptive tests SPSS was using with data.

\section{RESULTS AND DISCUSSION}

It can be surveyed with 32 workers which has $75 \%$ is man and 25\% is women. Also, 25\% employee finished university and 6 persons of them are fisheries engineer. A quarter of the population have high school diploma. Others are finish primary or secondary school. 56\% person of workers is married, 037 person is single and 6\% person is divorced or widow. According to results, main risky areas in fish farms generally find at fish tanks or ponds (85\%), working at height areas (78\%), wet slippery floor (75\%), electrical current (72\%), chemicals and disinfectants (70\%), heavy working conditions (70\%), physical conditions - hot, cold, humidity (65\%), biological risk factors such as infections (65\%), psychosocial risks and shift works (60\%) for hatchery phase. In cage system, one of the important workplace is open sea (95\%). Other situations are, physical conditions - hot, cold, humidity and pressure (95\%), wet slippery floor (85\%), electrical current (75\%), pounding machine parts (68\%), biological risks such as predators (65\%), sun and brightness (60\%), noisy area (\%50). At last, fish farm which contains fish pools (Nursery Phase) are involved various risky places such as; working at height areas (90\%), electrical current (85\%), heavy working conditions (80\%), chemicals 
and disinfectants (75\%), biological risk factors (72\%), psychosocial risks and shift works (68\%), and physical conditions - hot, cold, humidity (62\%). Furthermore, disease and accidents problems are indicated in workers such as musculo skeletal problems and accidents, fractures, dislocations, and poundings (90\%), skin problems or allergy (86\%), eye and ear problems (85\%), respiratory problems mainly caused by physical risk factors (82\%), gastrointestinal disorders which is related with irregular nutrition (78\%), psychosocial problems mainly heavy duty terms and shift works and low incomes are impact to health of aquaculture employee.

\section{CONCLUSION AND RECOMMENDATIONS}

In Turkey, marine aquaculture business and farm conditions are growing day by day. Moreover, tonnage of fish ponds or cages are rise. In contrast, working conditions are more heavy and dangerous against growing of the farms. In this situation leads to need taken preventative effects on job security and protective equipment for workers and employers [6, 7, 8 and 9]. However, heavy duty condition in aquaculture workplace which required legislation, mandatory, and laws that have to be safeguard for labors [5]. Thus, a new social security system is needed to be set up for workers that protect their health and family.

\section{NOTICE}

This work is organized 05-08 September 2018 Pristina-Kosovo Third International Science Symposium (ISS2018-NWSA) ISS New Horizons in Science-was presented as an oral presentation at the conference. The NWSA publication and writing basics has been rearranged according to the rules of writing.

\section{REFERENCES}

[1] ILO, (2003). Global Strategy on Occupational Safety and Health, Conclusions Adopted by the International Labour Conference at Its 91st, Session, pp:3-4.

[2] Antonsen, S., (2009). Safety Culture: Theory, Method and Improvement, Ashgate Publishing Limited, England

[3] Fleming, M., (2001). Safety Culture Maturation Model HSE Books, $\mathrm{pp}: 3-6$.

[4] Perçin, F. and Haydan, E., (2017). Maturation Pyramis of Occupational Health and Safety. Engineering Sciences, 12 (4), 262-270. Retrieved from, http://dergipark.gov.tr/nwsaeng/issue/31529/345176

[5] Myers, M. L., and Durborow, R. M. (2012). Aquacultural Safety and Health. In Health and environment in aquaculture. InTech.pp. 385-400.

[6] Myers, M.L., (2010). Review of Occupational Hazards Associated with Aquaculture. Journal of Agromedicine. Vol:15, pp:412-426.

[7] Perçin, F., Akyol, O., Davas, A., and Saygı, H., (2012). Occupational health of Turkish Aegean Small-Scale Fishermen. Occupational Medicine, 62:148-151.

[8] Moreau, D.T.R. and Neis, B., (2009). Occupational Health and Safety Hazards in Atlantic Canadian Aquaculture: Laying the Groundwork for Prevention. Marine Policy. Volume:33, Issue:2, pp: $401-411$.

[9] Perçin, F., (2017). Accidents and Diseases of Fishermen in İzir Province. In: Fisheries of İzmir Province. Kınacigil, T., Tosunoğlu, Z., Çaklı, Ş., Bey, E., Öztürk, H., Eds., pp:179-187. (ISBN: 978-975-18-0222-4) İmir Büyükşehir Belediyesi Konakİzmir (in Turkish). 